\title{
Front Matter: Volume 9737
}

, "Front Matter: Volume 9737," Proc. SPIE 9737, Synthesis and Photonics of Nanoscale Materials XIII, 973701 (11 May 2016); doi: 10.1117/12.2239305

SPIE. Event: SPIE LASE, 2016, San Francisco, California, United States 


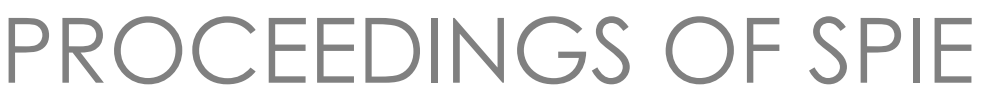

\title{
Synthesis and Photonics of Nanoscale Materials XIII
}

\author{
Andrei V. Kabashin \\ David B. Geohegan \\ Jan J. Dubowski \\ Editors
}

15 and 17 February 2016

San Francisco, California, United States

Sponsored and Published by

SPIE 
The papers in this volume were part of the technical conference cited on the cover and title page. Papers were selected and subject to review by the editors and conference program committee. Some conference presentations may not be available for publication. Additional papers and presentation recordings may be available online in the SPIE Digital Library at SPIEDigitallibrary.org.

The papers reflect the work and thoughts of the authors and are published herein as submitted. The publisher is not responsible for the validity of the information or for any outcomes resulting from reliance thereon.

Please use the following format to cite material from these proceedings:

Author(s), "Title of Paper," in Synthesis and Photonics of Nanoscale Materials XIII, edited by Andrei V. Kabashin, David B. Geohegan, Jan J. Dubowski, Proceedings of SPIE Vol. 9737 (SPIE, Bellingham, WA, 2016) Six-digit Article CID Number.

ISSN: 0277-786X

ISSN: 1996-756X (electronic)

ISBN: 9781628419726

Published by

SPIE

P.O. Box 10, Bellingham, Washington 98227-0010 USA

Telephone +1 3606763290 (Pacific Time) · Fax +1 3606471445

SPIE.org

Copyright (C) 2016, Society of Photo-Optical Instrumentation Engineers.

Copying of material in this book for internal or personal use, or for the internal or personal use of specific clients, beyond the fair use provisions granted by the U.S. Copyright Law is authorized by SPIE subject to payment of copying fees. The Transactional Reporting Service base fee for this volume is $\$ 18.00$ per article (or portion thereof), which should be paid directly to the Copyright Clearance Center (CCC), 222 Rosewood Drive, Danvers, MA 01923. Payment may also be made electronically through CCC Online at copyright.com. Other copying for republication, resale, advertising or promotion, or any form of systematic or multiple reproduction of any material in this book is prohibited except with permission in writing from the publisher. The CCC fee code is $0277-786 \mathrm{X} / 16 / \$ 18.00$.

Printed in the United States of America.

Publication of record for individual papers is online in the SPIE Digital Library.

\section{SPIE. DIGITAL}

Paper Numbering: Proceedings of SPIE follow an e-First publication model. A unique citation identifier (CID) number is assigned to each article at the time of publication. Utilization of CIDs allows articles to be fully citable as soon as they are published online, and connects the same identifier to all online and print versions of the publication. SPIE uses a six-digit CID article numbering system structured as follows:

- The first four digits correspond to the SPIE volume number.

- The last two digits indicate publication order within the volume using a Base 36 numbering system employing both numerals and letters. These two-number sets start with $00,01,02,03,04$, $05,06,07,08,09,0 A, 0 B \ldots$. OZ, followed by 10-1Z, 20-2Z, etc. The CID Number appears on each page of the manuscript. 


\title{
Contents
}

\author{
$\checkmark$ Authors \\ vii Conference Committee
}

SESSION 1 LASER SYNTHESIS OF NANOMATERIALS I

973703 Direct laser fabrication of nanowires on semiconductor surfaces [9737-2]

$973704 \quad$ Modeling nanoparticle formation by laser ablation and by spark discharges (Invited Paper) [9737-3]

\section{SESSION 2 LASER SYNTHESIS OF NANOMATERIALS II}

$973706 \quad$ Modeling of heat release in aqueous suspensions of solid state nanoparticles under electromagnetic radio-frequency irradiation (Invited Paper) [9737-5]

973708 Ejection of glass melts and generation of nanofibers from the back surface of a glass plate by pulsed UV laser irradiation [9737-7]

973709 Laser ablative nanostructuring of $\mathrm{Au}$ in liquid ambience in continuous wave illumination regime [9737-8]

9737 OA Si nanoparticles as sensitizers for radio frequency-induced cancer hyperthermia [9737-9]

\section{SESSION 3 NANOSTRUCTURES FOR TELECOMMUNICATIONS, ENERGY, AND BIOMEDICAL APPLICATIONS}

9737 OC Quantum-dot based ultrafast photoconductive antennae for efficient THz radiation (Invited Paper) [9737-11]

9737 OD Phase-sensitive plasmonics biosensors: from bulk to nanoscale architechtures and novel functionalities [9737-12]

9737 OF Structural properties of gold-silicon nanohybrids formed by femtosecond laser ablation in water at different fluences [9737-14]

\section{SESSION 4 NANOPARTICLE-ENHANCED DIAGNOSTIC DEVICES}

9737 Ol Zinc oxide nanowire gamma ray detector with high spatiotemporal resolution [9737-17] 
SESSION 5 LASER-INDUCED NANOSTRUCTURES I: LIPSS: JOINT SESSION WITH CONFERENCES 9735 AND 9737

9737 OK High density semiconductor nanodots by direct laser fabrication [9737-19]

SESSION 6 LASER-INDUCED NANOSTRUCTURES II: JOINT SESSION WITH CONFERENCES 9735 AND 9737

$9737 \mathrm{OL}$ Femtosecond laser irradiation of dielectric materials containing randomly arranged nanoparticles [9737-20] 


\section{Authors}

Numbers in the index correspond to the last two digits of the six-digit citation identifier (CID) article numbering system used in Proceedings of SPIE. The first four digits reflect the volume number. Base 36 numbering is employed for the last two digits and indicates the order of articles within the volume. Numbers start with 00, 01, 02, 03, 04, 05, 06, 07, 08, 09, OA, OB...0Z, followed by 10-12, 20-2Z, etc.

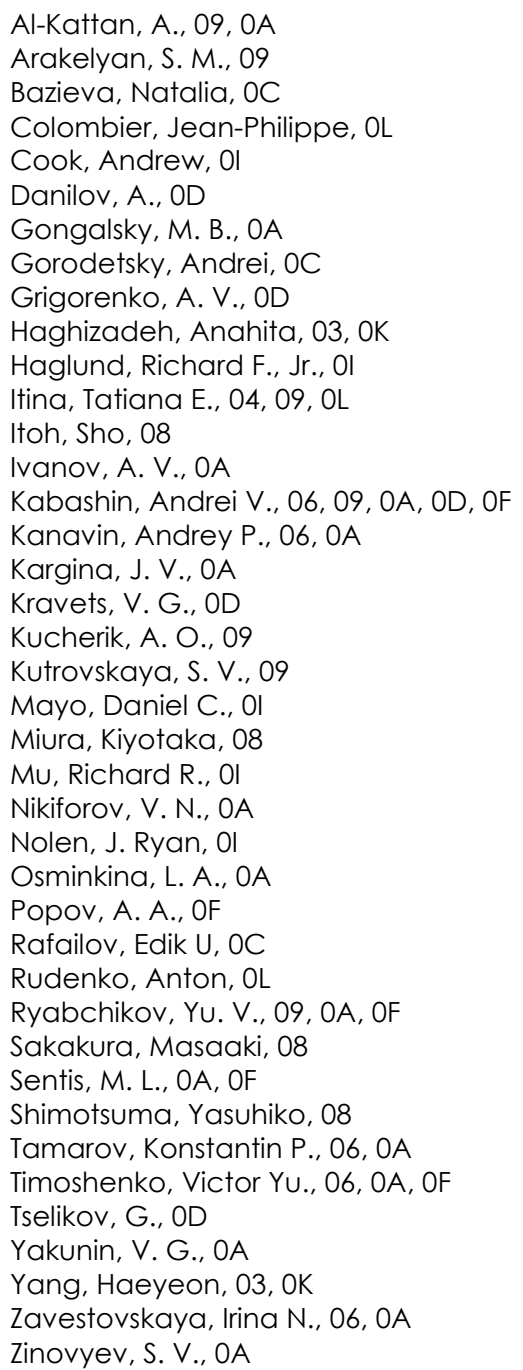


Proc. of SPIE Vol. $9737973701-6$

Downloaded From: https://www.spiedigitallibrary.org/conference-proceedings-of-spie on 25 Apr 2023 Terms of Use: https://www.spiedigitallibrary.org/terms-of-use 


\section{Conference Committee}

Symposium Chairs

Guido Hennig, Daetwyler Graphics AG (Switzerland)

Yongfeng Lu, University of Nebraska-Lincoln (United States)

Symposium Co-chairs

Reinhart Poprawe, Fraunhofer-Institut für Lasertechnik (Germany)

Koji Sugioka, RIKEN (Japan)

Program Track Chairs

Henry Helvajian, The Aerospace Corporation (United States)

Alberto Piqué, U.S. Naval Research Laboratory (United States)

Conference Chairs

Andrei V. Kabashin, Aix-Marseille Université (France)

David B. Geohegan, Oak Ridge National Laboratory (United States)

Jan J. Dubowski, Université de Sherbrooke (Canada)

\section{Conference Program Committee}

Jason D. Fowlkes, Oak Ridge National Laboratory (United States)

Reuven Gordon, University of Victoria (Canada)

Costas P. Grigoropoulos, University of California, Berkeley

(United States)

Richard F. Haglund Jr., Vanderbilt University (United States)

Henry Helvajian, The Aerospace Corporation (United States)

Hiroshi Kumagai, Kitasato University (Japan)

Thomas K. Lippert, Paul Scherrer Institut (Switzerland)

Yongfeng Lu, University of Nebraska-Lincoln (United States)

Rajesh Menon, The University of Utah (United States)

Rahul Rao, Honda Research Institute USA, Inc. (United States)

Federico Rosei, Université du Québec (Canada)

James P. Schuck, The Molecular Foundry (United States)

Oleksandr Voznyy, University of Toronto (Canada)

Xianfan Xu, Purdue University (United States) 


\section{Session Chairs}

1 Laser Synthesis of Nanomaterials I

Andrei V. Kabashin, Aix-Marseille Université (France)

2 Laser Synthesis of Nanomaterials II

David B. Geohegan, Oak Ridge National Laboratory (United States)

3 Nanostructures for Telecommunications, Energy, and Biomedical Applications

Jan J. Dubowski, Université de Sherbrooke (Canada)

4 Nanoparticle-enhanced Diagnostic Devices

Tatiana E. Itina, Laboratoire Hubert Curien (France)

Richard F. Haglund Jr., Vanderbilt University (United States)

5 Laser-induced Nanostructures I: LIPSS: Joint Session with Conferences 9735 and 9737

Andrei V. Kabashin, Aix-Marseille Université (France)

6 Laser-induced Nanostructures II: Joint Session with Conferences 9735 and 9737

Jörn Bonse, Bundesanstalt für Materialforschung und -prüfung (Germany) 